Iğdır Üniversitesi Fen Bilimleri Enstitüsü Dergisi, 11(2): 1014-1026, 2021

Journal of the Institute of Science and Technology, 11(2): 1014-1026, 2021

Elektrik-Elektronik Mühendisliği / Electrical and Electronics Engineering

ISSN: 2146-0574, eISSN: 2536-4618

Araştırma Makalesi / Research Article

DOI: 10.21597/jist.819389

Geliş tarihi / Received: 02-11-2020

Kabul tarihi / Accepted: 04-02-2021

Atıf İçin: Yılmaz M, Can K, Başçi A, 2021. İkili Tank Sisteminin Sıvı Seviye Kontrolü için Genetik Algoritma Tabanlı PI+İleri Besleme Kontrolcü. Iğdır Üniversitesi Fen Bilimleri Enstitüsü Dergisi, 11(2): 1014-1026.

To Cite: Yılmaz M, Can K, Baş̧i A, 2021. PI+Feed Forward Controller Tuning Based on Genetic Algorithm for Liquid Level Control of Coupled-Tank System. Journal of the Institute of Science and Technology, 11(2): 1014-1026.

\title{
PI+Feed Forward Controller Tuning Based on Genetic Algorithm for Liquid Level Control of Coupled-Tank System
}

\author{
Mehmet YILMAZ ${ }^{1}$, Kaan CAN ${ }^{1}$, Abdullah BAŞÇ $\dot{1}^{1 *}$
}

\begin{abstract}
One of the main problems in the control of the coupled tank liquid level systems, which are used frequently in water treatment systems and petrochemical industry today, is to determine the water flow rate between the two tanks. In this paper, proportional-integral + feed forward control method $(\mathrm{PI}+\mathrm{FF})$, whose parameters are determined using genetic algorithm (GA), one of the heuristic optimization methods, is used to solve this problem. In addition, in order to show the performance of the GA-based controller, the PI+FF controller that PI parameters obtained using the Ziegler-Nichols (ZN) method are applied to the same system and the real-time application results of both controllers are compared. The experimental results showed that the controller, which parameters are determined by GA, reached the desired reference value with less settling time and less overshooting when it compared to the Z-N method based controller, and also it has given faster response to sudden changes in the system.
\end{abstract}

Keywords: Liquid level systems, Ziegler-Nichols method, Genetic Algorithm, PI controller

\section{İkili Tank Sisteminin Sıvı Seviye Kontrolü için Genetik Algoritma Tabanlı PI+İleri Besleme Kontrolcü}

ÖZET: Günümüzde su arıtma sistemlerinde ve petrokimya endüstrisinde sıklıkla kullanılan ikili tank Sıvı seviye sistemlerinin kontrolündeki en temel problemlerden biri iki tank arasındaki sıvı akış oranının belirlenmesidir. Bu çalışmada bu problemi gidermek amacıyla oransal-integral (PI) + ileri besleme (FF) kontrolcünün (PI+FF) parametreleri sezgisel optimizasyon yöntemlerinden genetik algoritma (GA) kullanılarak belirlenmiş ve ikili tank sistemine uygulanmıştır. Ayrıca GA tabanlı kontrolcünün performansını göstermek amacıyla Ziegler-Nichols (Z-N) yöntemi kullanılarak parametreleri elde edilen PI+FF kontrol yöntemi aynı sisteme uygulanmış ve her iki kontrolcünün gerçek zamanlı uygulama sonuçları karşılaştırılmıştır. Deneysel sonuçlar, parametreleri GA ile belirlen kontrolcünün Z-N yöntemi kullanılarak elde edilen kontrolcüye oranla istenilen referans değere daha küçük yerleşme zamanı ve daha az yüzde aşım ile ulaştığı ve ayrıca sistemde meydana gelen ani değişimlere daha hızlı tepki verdiği gözlemlenmiştir.

Anahtar Kelimeler: Sıvı seviye sistemleri, Ziegler-Nichols yöntemi, Genetik Algoritma, PI kontrolör

\footnotetext{
${ }^{1}$ Mehmet YILMAZ (Orcid ID: 0000-0001-7624-4245), Kaan CAN (Orcid ID: 0000-0002-6597-2797), Abdullah BAŞÇİ (Orcid ID: 0000-0003-4141-2880), Atatürk Üniversitesi, Mühendislik Fakültesi, Elektrik Elektronik Mühendisliği Bölümü, Erzurum, Türkiye

*Sorumlu Yazar/Corresponding Author: Abdullah BAŞÇİ, e-mail: abasci@atauni.edu.tr
} 


\section{INTRODUCTION}

The main problem in liquid level control systems, which are frequently used in nuclear power plants, water treatment plants and petrochemical industry in recent years, is to determine the liquid flow rate between tanks (Başçi and Derdiyok, 2016; Sekban et al., 2020). In such a high-cost systems, a large amount of product and cost is lost as a result of incorrect design of the control systems. Traditional PI controller is generally used for the control of these systems because of its advantages such as simple and easy to apply (Khalkhali, 2016). There are many studies in the literature to determine the optimum values of the parameters to increase the performance of the PI controller. Singh et al. designed a proportionalintegral-derivative (PID) controller for controlling of a coupled tank liquid level system used in water treatment plants and facilities such as food processing (Singh et al., 2014). Traditional methods and GA were used to determine the gain expressions of the designed controller. It has been observed that the PID controller whose parameters were determined with the GA showed better results than the others. Nawi et al. proposed a new optimization algorithm for determining PI controller parameters used in liquid level control systems (Nawi et al., 2011). The proposed new algorithm consists of GA and artificial immune system. Simulation results showed that the proposed algorithm is more robust than the others. Lian et al. designed a neuro-fuzzy logic controller (NFLC) that parameters are determined by GA for a coupled tank liquid level control system (Lian et al., 1998). Experimental results showed that the NFLC is more robust than the FLC and PID controller. Mohideen et al. used model reference adaptive control method whose parameters were determined by real-coded GA for hybrid tank system (Mohideen et al., 2013). Simulation results showed that the proposed controller followed the reference level better than PID controller in nonlinear system. Liang proposed the fuzzy PID control method for the coupled tank liquid level control (Liang, 2011). Experimental results showed that the proposed control method improved the control effect. Katal et al. used PID controller that parameters were determined by Bat algorithm (BA) for liquid level control of coupled tank system (Katal et al., 2014). Simulation results showed that BA based PID controller showed better results than PID controller whose parameters were determined with different algorithms. Tijjani et al., applied PI, PI+FF and model predictive control (MPC) methods for the liquid level control of the coupled tank system (Tijjani et al., 2017). In order to determine the PI controller parameter values Z-N, pole placement and Ciancone correlation methods were used. As a result of the simulation studies, they observed that the PI+FF and MPC methods have shown similar successful results in liquid level control. In addition, it has been observed that MPC have shown better results than PI and PI+FF in terms of time response and disturbance handling criteria. John et al., performed liquid level control of a tank with the backstepping algorithm (John et al., 2017). They compared the performance of PID and backstepping control methods for different reference liquid levels. Simulation results showed that the backstepping algorithm have given better response than the PID controller while tracking the desired reference liquid level without overshoot and in less settling time.

In this paper, $\mathrm{PI}+\mathrm{FF}$ controller is designed to control of single and coupled tank liquid level system. In order to determine the PI controller parameters Z-N and GA methods are used. Also, real-time applications have been realized to compare the performances of the two algorithms in a single tank and coupled tank liquid level control system.

\section{MATERIALS AND METHODS}

\section{Mathematical Model of Tank Liquid Level Control System}

Most of the systems used in industrial applications are nonlinear systems due to their complex structure. While designing the controllers for these systems, a mathematical model is often needed. Generally, the mathematical model of the liquid level control system shown in Figure 1, which consists 
of 2 tanks, 1 water pump and 1 water container, is modeled separately for a single tank and a coupled tank, respectively.

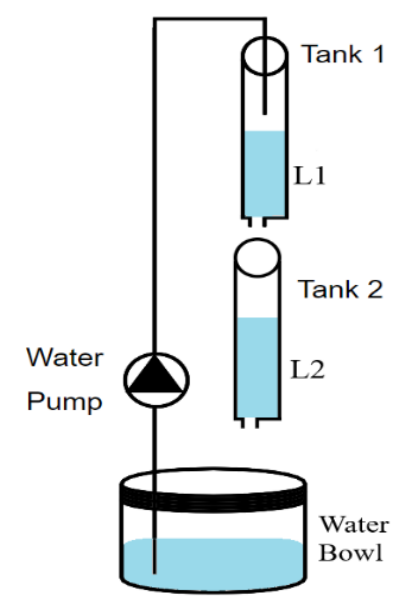

Figure 1. The coupled tank liquid level model

Before the beginning, we give the nomenclature used in this paper as:

- $f_{1_{i}} \quad$ Volumetric flow rate of liquid input to the tank $1\left(\frac{\mathrm{cm}^{3}}{\mathrm{~s}}\right)$

- $f_{1_{0}} \quad$ Volumetric flow rate of the liquid output to the tank $1\left(\frac{\mathrm{cm}^{3}}{\mathrm{~s}}\right)$

- $f_{2_{0}} \quad$ Volumetric flow rate of the liquid output to the tank $2\left(\frac{\mathrm{cm}^{3}}{\mathrm{~s}}\right)$

- $m$ Pomp flow constant $\left(\frac{\mathrm{cm}^{3}}{\mathrm{~s} . V}\right)$

- $V_{p} \quad$ Pomp voltage $(V)$

- $S_{1_{0}} \quad$ Tank 1 liquid flow outlet cross sectional area $\left(\mathrm{cm}^{2}\right)$

- $S_{2_{0}} \quad$ Tank 2 liquid flow outlet cross sectional area $\left(\mathrm{cm}^{2}\right)$

- $V_{1_{0}} \quad$ Outflow velocity of tank $1\left(\frac{\mathrm{cm}}{\mathrm{s}}\right)$

- $V_{2_{0}} \quad$ Outflow velocity of tank $2\left(\frac{\mathrm{cm}}{\mathrm{s}}\right)$

- $D_{1_{0}} \quad$ Outlet diameter of tank $1(\mathrm{~cm})$

- $D_{2_{0}} \quad$ Outlet diameter of tank $2(\mathrm{~cm})$

- $\quad L_{1} \quad$ Tank 1 liquid level $(\mathrm{cm})$

- $\quad L_{2} \quad$ Tank 2 liquid level $(\mathrm{cm})$

- $S_{1_{t}} \quad$ Tank 1 liquid flow inside cross sectional area $\left(\mathrm{cm}^{2}\right)$

- $S_{2_{t}} \quad$ Tank 2 liquid flow inside cross sectional area $\left(\mathrm{cm}^{2}\right)$

- $g$ Gravity constant $\left(\frac{\mathrm{cm}}{\mathrm{s}^{2}}\right)$

\section{Single Tank Liquid Level Model}

In the single tank liquid level control system, liquid flow is provided to tank 1 by the voltage applied to the pump. The control system depends on the volumetric flow rate of the liquid input and output to the tank 1. The volumetric flow rate of the liquid input for tank 1 is given in Equation 1and volumetric flow rate of the liquid leaving from tank 1 is given in Equation 2 (Quanser, 2005), respectively.

$$
\begin{aligned}
& f_{1_{i}}=m V_{p} \\
& f_{1_{0}}=S_{1_{0}} V_{1_{0}}
\end{aligned}
$$


The cross-sectional area of the place where the liquid is filled into tank 1 by the pump is given in Equation 3, and the outflow velocity from the tank 1 is given in Equation 4.

$$
\begin{gathered}
S_{1_{0}}=\frac{\left(\pi D_{1_{0}}^{2}\right)}{4} \\
V_{1_{0}}=\sqrt{2 L_{1} g}
\end{gathered}
$$

When the expressions in Equation 3 and Equation 4 are rewritten in Equation 2 and the mass balance principle is taken into consideration, the expression in Equation 5 and 6 is obtained.

$$
\begin{aligned}
& \dot{L}_{1}=\frac{\left(f_{1_{i}}-f_{1_{0}}\right)}{S_{1_{t}}} \\
& \dot{L}_{1}=\frac{\left(m V_{p}-S_{1_{0}} \sqrt{2 L_{1} g}\right)}{S_{1_{t}}}
\end{aligned}
$$

Since the expression in Equation 6 is nonlinear, the static balance point $\left(V_{p_{0}}, L_{1_{0}}\right)$ should be selected in order to determine the pump voltage suitable for the desired liquid level. In case of equilibrium, the derivative expression in Equation 6 will be zero and the pump voltage will be as in Equation 7.

$$
V_{p_{0}}=\frac{S_{1_{0}} \sqrt{2 L_{1_{0}} g}}{m}
$$

In order to control the pump voltage, the equation of motion is linearized around the operating point. The operating limits of the system are determined with small deviations $\left(V_{p_{1}}, L_{1_{1}}\right)$ around the operating point. In this case, the pump voltage and liquid level are expressed as in Equation 8 and Equation 9, respectively.

$$
\begin{aligned}
& V_{p}=V_{p_{0}}+V_{p_{1}} \\
& L_{1}=L_{1_{0}}+L_{1_{1}}
\end{aligned}
$$

The result of the Taylor series is the linear model of the system and given in Equation 10.

$$
\dot{L}_{1_{1}}=\frac{m V_{p_{1}}}{S_{1_{t}}}-\frac{\left(S_{1_{0}} \sqrt{2} L_{1_{1}} g\right)}{2 S_{1_{t}} \sqrt{g L_{1_{0}}}}
$$

In this case, the open loop transfer function of the tank 1 is obtained as given below;

$$
G_{1}(s)=\frac{m \sqrt{2 g L_{1_{0}}}}{S_{1_{t}} \sqrt{2 g L_{1_{0}}} s+S_{1_{0}} g}=\frac{3.24}{15.23 s+1}
$$

\section{Coupled Tank Liquid Level Model}

In the coupled tank liquid level model, liquid flow is provided to tank 1 by the voltage applied to the pump. The desired amount of liquid for tank 2 is provided by tank 1 . The volumetric flow rate of the liquid input to tank 2 is given in Equation 12. 


$$
f_{2_{0}}=S_{2_{0}} V_{2_{0}}
$$

The cross-sectional area of the place where the liquid output from tank 1 to tank 2 is given in Equation 13, and the outflow velocity from the tank 2 is given in Equation 14, respectively.

$$
\begin{aligned}
& S_{2_{0}}=\frac{\left(\pi D_{2_{0}}{ }^{2}\right)}{4} \\
& V_{2_{0}}=\sqrt{2 L_{2} g}
\end{aligned}
$$

The mathematical model of the coupled tank system according to the mass balance principle is given in Equation 15.

$$
\dot{L}_{2}=\frac{\left(-S_{2_{0}} \sqrt{2 L_{2} g}+S_{1_{0}} \sqrt{2 L_{1} g}\right)}{S_{2_{t}}}
$$

Since the expression in Equation 15 is nonlinear, the static balance point $\left(L_{1_{0}}, L_{2_{0}}\right)$ should be selected in order to determine the nominal liquid level which is suitable for the desired liquid level for the tank 2. In the case of equilibrium, the derivative expression will be zero in the Equation 15, and the nominal water level can be expressed as given in Equation 16.

$$
L_{1_{0}}=\frac{S_{2_{0}}^{2} L_{2_{0}}}{S_{1_{0}}^{2}}
$$

In order to control the liquid level of the tank 2, the equation of motion is linearized around the operating point. The operating limits of the system are determined by small deviations around the operating point $\left(L_{1_{1}}, L_{2_{1}}\right)$.

$$
\begin{aligned}
& L_{1}=L_{1_{0}}+L_{1_{1}} \\
& L_{2}=L_{2_{0}}+L_{2_{1}}
\end{aligned}
$$

With the Taylor series approach, the linear model of the tank 2 system is obtained in Equation 19.

$$
\dot{L}_{2_{1}}=\frac{1}{2}\left(\frac{S_{1_{0}} \sqrt{2} L_{1_{1}} g}{S_{2_{t}} \sqrt{g L_{1_{0}}}}-\frac{S_{2_{0}} \sqrt{2} L_{2_{1}} g}{S_{2_{t}} \sqrt{g L_{2_{0}}}}\right)
$$

In this case, the open loop transfer function of the tank 2 is obtained as;

$$
G_{2}(s)=\frac{S_{1_{0}} g \sqrt{L_{2_{0}}}}{S_{2_{t}} \sqrt{2 g L_{1_{0}} L_{2_{0}}} s+S_{2_{0}} g \sqrt{L_{1_{0}}}}=\frac{1}{15.23 s+1}
$$

Moreover, the transfer function of coupled tank system is obtained as given below;

$$
G(s)=G_{1}(s) \cdot G_{2}(s)=\frac{0.01396}{s^{2}+0.1313 s+0.004309}
$$




\section{Control Method}

In this paper, PI+FF control technique is used to control the liquid level in the tanks. The feed forward control technique has been used to eliminate the disturbance effect that may occur during liquid leaving from the tank. The PI controller is formed by adding the integral (I) effect to the proportional (P) controller. The most important advantage of this controller is that it eliminates the steady state error and compensates dynamic deviations by taking the past values of the error into consideration (Ogata,2015). Basically, the working principle is to multiply the error expression obtained by comparing the reference signal and the output signal with the appropriate gain parameters $\left(K_{p}, K_{i}\right)$ and send the new control signal to the system. It is frequently used in real-time applications due to its simple structure. Figure 2 shows the liquid level control block diagram for single tank and Figure 3 shows coupled tank liquid level control block diagram.

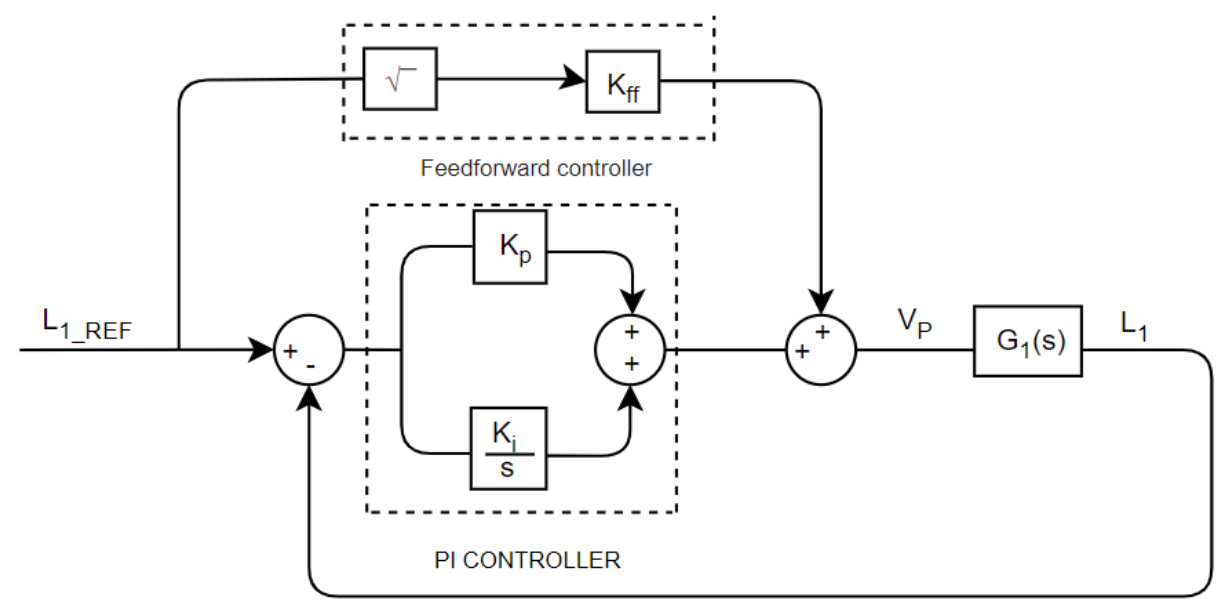

Figure 2. Liquid level control block diagram for single tank

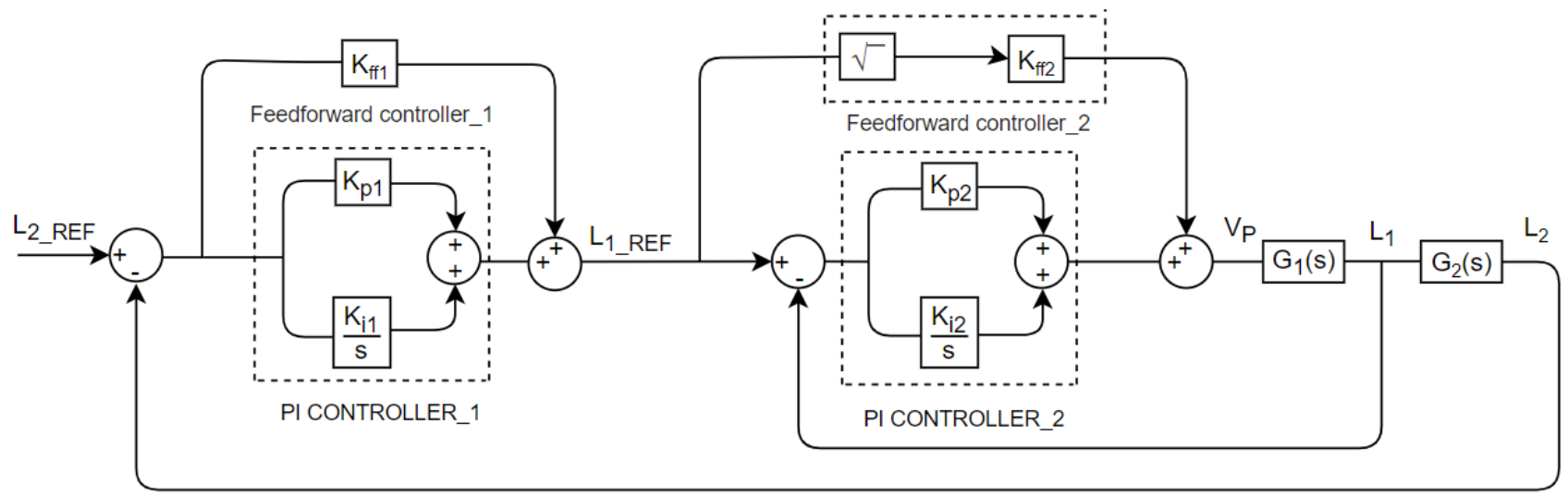

Figure 3. Liquid level control block diagram for the coupled tank

\section{Determining the Controller Gain Parameters}

In order to determine PI controller parameters, Z-N and GA methods are used. The Z-N method was discovered in 1942 by John G. Ziegler and Nathaniel B. Nichols. It is one of the most preferred methods to find the optimum PI parameters $\left(\mathrm{K}_{\mathrm{p}}, \mathrm{K}_{\mathrm{i}}\right)$. In this study, optimum parameters were found by using open loop Z-N method. In the open loop Z-N method, the open loop gain of the system is obtained by applying unit step to the input. The open loop gains for single and coupled tank are given in Figure 4. The inflection point is determined in the unit step response of the system. The delay time (L) and time 
constant $(\mathrm{T})$ of the system are calculated by drawing a tangent to the $\mathrm{x}$ axis from the inflection point. With the help of Table 1, PI controller parameters are found.

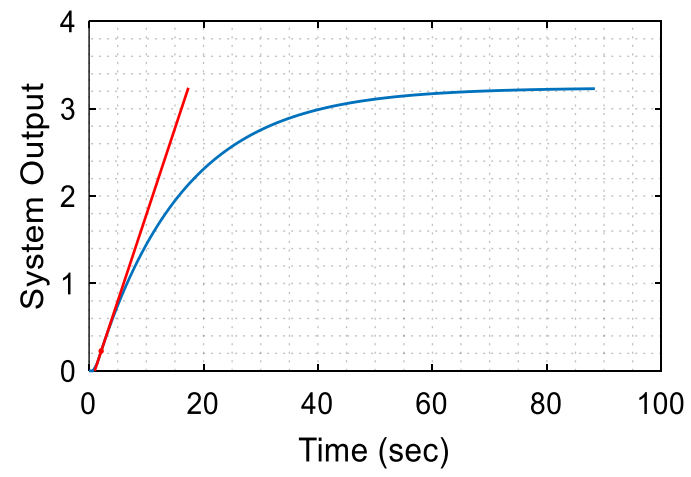

Figure 4. a) Step response of single tank

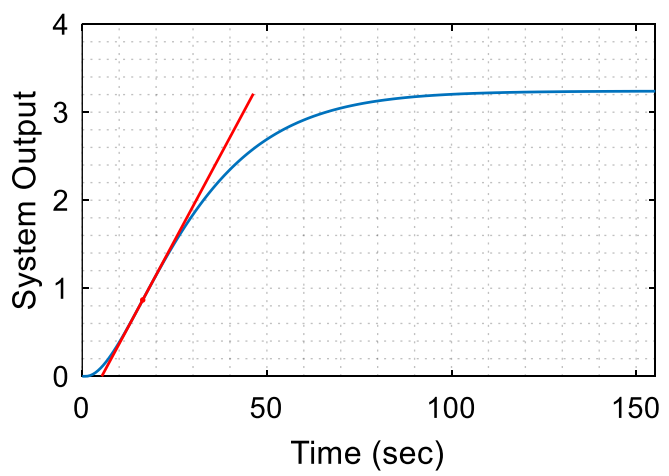

b) Step response of coupled tank

Table 1. Optimum parameter values according to open loop Z-N method

\begin{tabular}{c|ccl}
\hline \multirow{2}{*}{ Controllers } & \multicolumn{3}{c}{ Parameters } \\
\cline { 2 - 4 } & $\mathbf{K}_{\mathbf{P}}$ & \multicolumn{1}{|c}{$\mathbf{T}_{\mathbf{I}}$} & $\mathbf{T}_{\mathbf{d}}$ \\
\hline $\mathbf{P}$ & $\mathrm{T} / \mathrm{L}$ & $\infty$ & 0 \\
$\mathbf{P I}$ & $0.9 \mathrm{~T} / \mathrm{L}$ & $\mathrm{L} / 0.3$ & 0 \\
$\mathbf{P I D}$ & $1.2 \mathrm{~T} / \mathrm{L}$ & $2 \mathrm{~L}$ & $\mathrm{~L} / 2$ \\
\hline
\end{tabular}

Where $L=0.9755 \mathrm{sec}$ and $T=16.373 \mathrm{sec}$ are obtained for tank 1 and also, $L=5.287 \mathrm{sec}$ and $T=$ $40.96 \mathrm{sec}$ are found for tank 2, respectively. The GA developed for the first time by John Holland in 1975, is the first and most well-known heuristic optimization algorithm. The algorithm consists of 3 basic concepts: reproduction, crossover and mutation (Çelebi and Başçi, 2016). The most frequently preferred fitness functions in solving optimization problems with GA are integral absolute error (IAE), integral square error (ISE), integral time absolute error (ITAE) and integral time square error (ITSE).

$$
\begin{gathered}
I A E=\int|e(t)| d t \\
I S E=\int e(t)^{2} d t \\
I T A E=\int t|e(t)| d t \\
I T S E=\int t e(t)^{2} d t
\end{gathered}
$$

Besides, GA flowchart is given in Figure 5. Fitness functions are used when finding PI parameters with the GA. The parameter values that make the fitness function minimum are taken as optimal values (Khalkhali, 2016). One of the important functions created with parameter combinations is given in Equation 26.

$\operatorname{Cos} t F=\lambda M+(1-\lambda) t_{s}$

In Equation 26, $M$ is the overshooting and $t_{s}$ indicates the settling time. If $\lambda=0.5$, then the expression in Equation 27 is obtained as; 


$$
\operatorname{Cos} t F=(0.5) M+(0.5) t_{s}
$$

Thus, the minimum value for the Cost $F$ system, which goes through the calculation process with GA, will provide the optimal parameters.

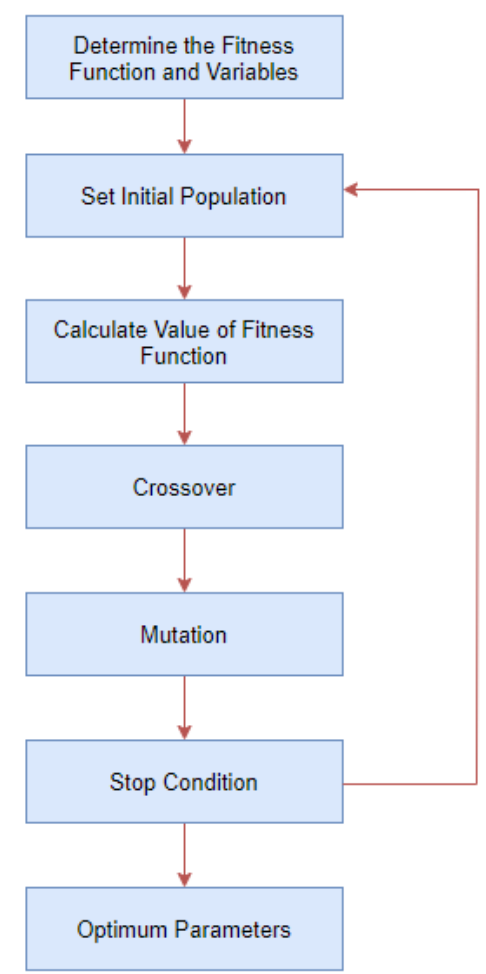

Figure 5. Genetic algorithm flowchart

Moreover, the controller parameters obtained for the single tank and the coupled tank systems are given in Table 2 and Table 3, respectively. Also, the experimental setup for coupled tank system is given in Figure 6.

Table 2. The obtained parameters of the both controllers for single tank

\begin{tabular}{c|cc}
\hline \multirow{2}{*}{ Parameters } & \multicolumn{2}{c}{ Controllers } \\
\cline { 2 - 3 } & Z-N based PI+FF Controller & GA based PI+FF Controller \\
\hline $\mathbf{K}_{\mathbf{f f}}$ & 2.3911 & 0.5455 \\
$\mathbf{K}_{\mathbf{p}}$ & 15.108 & 99.99 \\
$\mathbf{K}_{\mathbf{i}}$ & 4.446 & 19.99 \\
\hline
\end{tabular}

Table 3. The obtained parameters of the both controllers for coupled tank

\begin{tabular}{c|cc}
\hline \multirow{2}{*}{ Parameters } & \multicolumn{2}{|c}{ Controllers } \\
\cline { 2 - 3 } & Z-N based PI+FF Controller & GA based PI+FF Controller \\
\hline $\mathbf{K}_{\mathbf{f f} 1}$ & 1 & 0.9 \\
$\mathbf{K}_{\mathbf{p} 1}$ & 6.9723 & 2.68 \\
$\mathbf{K}_{\mathbf{i} 1}$ & 0.3956 & 15.27 \\
$\mathbf{K}_{\mathbf{f f 2}}$ & 2.3911 & 0.25 \\
$\mathbf{K}_{\mathbf{p} 2}$ & 15.108 & 99.384 \\
$\mathbf{K}_{\mathbf{i} 2}$ & 4.446 & 20.945 \\
\hline
\end{tabular}




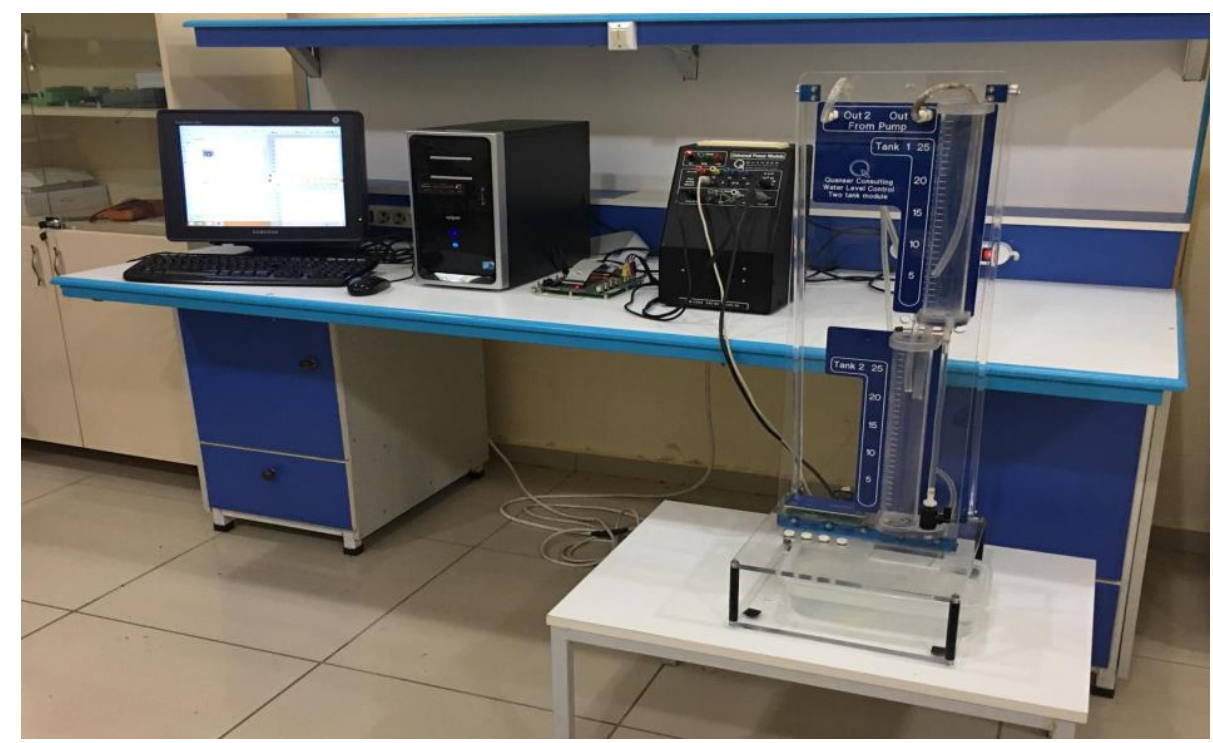

Figure 6. The experimental setup (Quanser, 2005)

\section{RESULTS AND DISCUSSION}

In this section, the proposed controller are tested on Quanser coupled tank liquid-level system and experimental results are presented. The GA and the Z-N based PI+FF controller results for step $(15 \mathrm{~cm})$ + square $( \pm 2 \mathrm{~cm})$ reference signal for tank1 are shown in Figure 7 and 8, respectively.
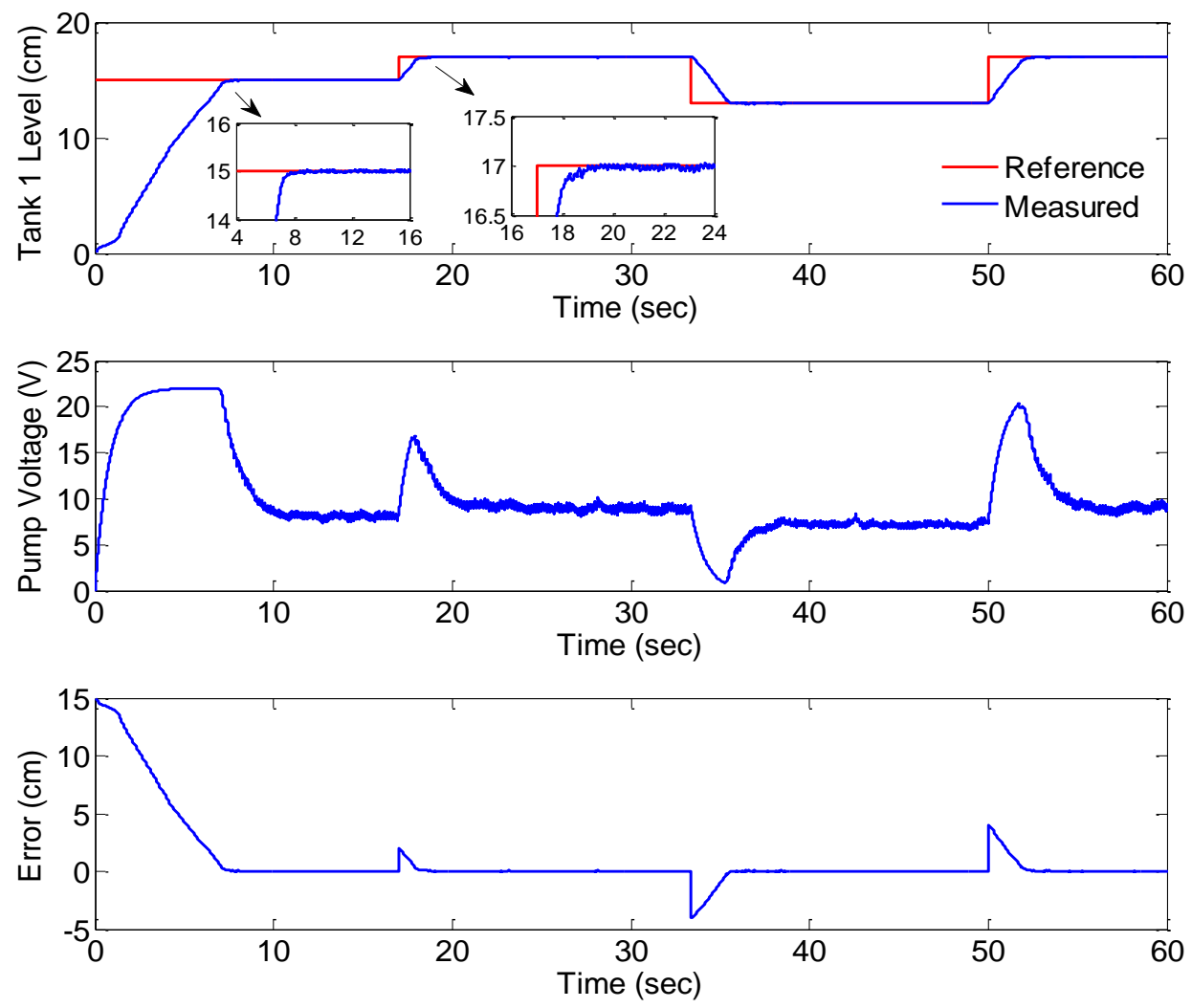

Figure 7. The GA based PI+FF controller results for single tank

For step part of the reference signal, The Z-N based controller has bigger overshoot and longer settling time when it compared to GA based controller. When square part of the reference signal is applied, the GA based controller has managed to follow the reference signal without overshoot. 

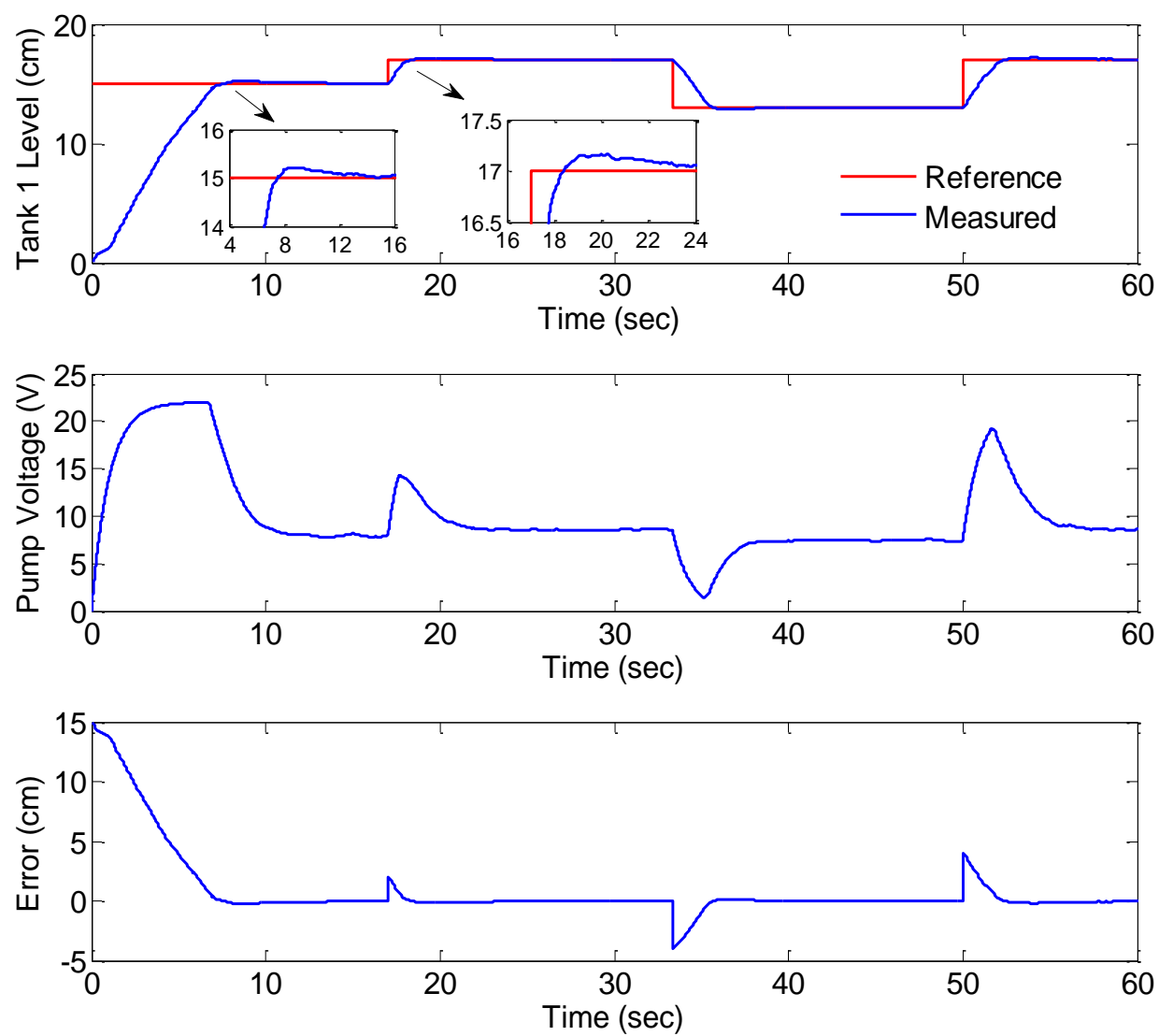

Figure 8. The Z-N based PI+FF controller for single tank

Moreover, $12.20 \%$ improvement has been achieved with the parameter values obtained by the GA as seen in Table 4 compared to the Z-N method. Although, the GA based controller has produced more chattering control signal due to reacting more sensitive and faster to error changes, it has provided more successful parameter optimization than the Z-N method and better reference level tracking as well.

Table 4. Mean absolute error values of the controllers for both tanks

\begin{tabular}{|c|c|c|c|c|c|c|c|}
\hline \multicolumn{8}{|c|}{ Mean Absolute Error (MAE) (cm²/2) } \\
\hline & \multicolumn{3}{|c|}{ Z-N based PI+FF Controller } & \multicolumn{3}{|c|}{ GA based PI+FF Controller } & \multirow{2}{*}{$\begin{array}{c}\text { Total } \\
\text { Improvement } \\
\%\end{array}$} \\
\hline \multirow{2}{*}{$\begin{array}{l}\text { Single } \\
\text { Tank }\end{array}$} & step & square & step + square & step & square & step + square & \\
\hline & 0.0935 & 0.2748 & 0.2434 & 0.0155 & 0.2552 & 0.2137 & 12.20 \\
\hline \multirow{2}{*}{$\begin{array}{c}\text { Coupled } \\
\text { Tank }\end{array}$} & step & sinusoidal & $\begin{array}{c}\text { step }+ \\
\text { sinusoidal }\end{array}$ & step & sinusoidal & $\begin{array}{c}\text { step + } \\
\text { sinusoidal }\end{array}$ & \multirow[b]{2}{*}{68.79} \\
\hline & 0.2295 & 0.1823 & 0.1910 & 0.0961 & 0.0513 & 0.0596 & \\
\hline
\end{tabular}

In Figure 9 and 10, the GA based and Z-N based controllers' results have been given for step (10 $\mathrm{cm})+$ sinusoidal $( \pm 2 \mathrm{~cm})$ reference signal for coupled tank, respectively. For tank 2 , the GA based controller has lower overshoot and is able to track the step reference very well when it compared to the $\mathrm{Z}-\mathrm{N}$ based controller. Also, the GA based controller has a lower settling time as well. Moreover, when the time varying part of the reference signal is applied, the GA based controller has followed the sinusoidal reference with minimum deviation when compared with the result of the Z-N based controller 
as seen from the Figure 9 and 10. Moreover, thanks to the parameters obtained by the GA, an improvement of $68.79 \%$ has been achieved throughout the reference signal tracking as seen from the Table 4.
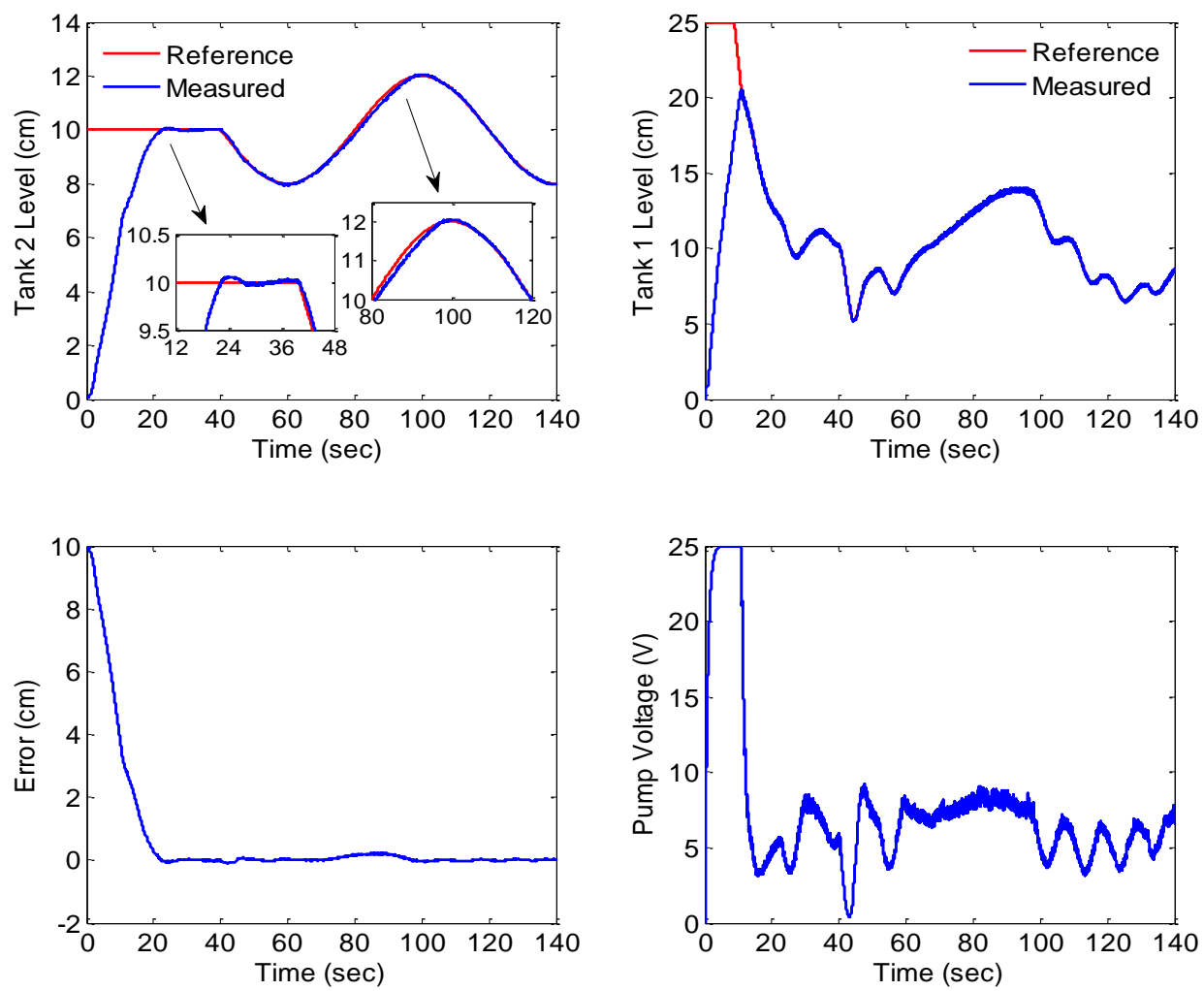

Figure 9. The GA based PI+FF controller results for coupled tank
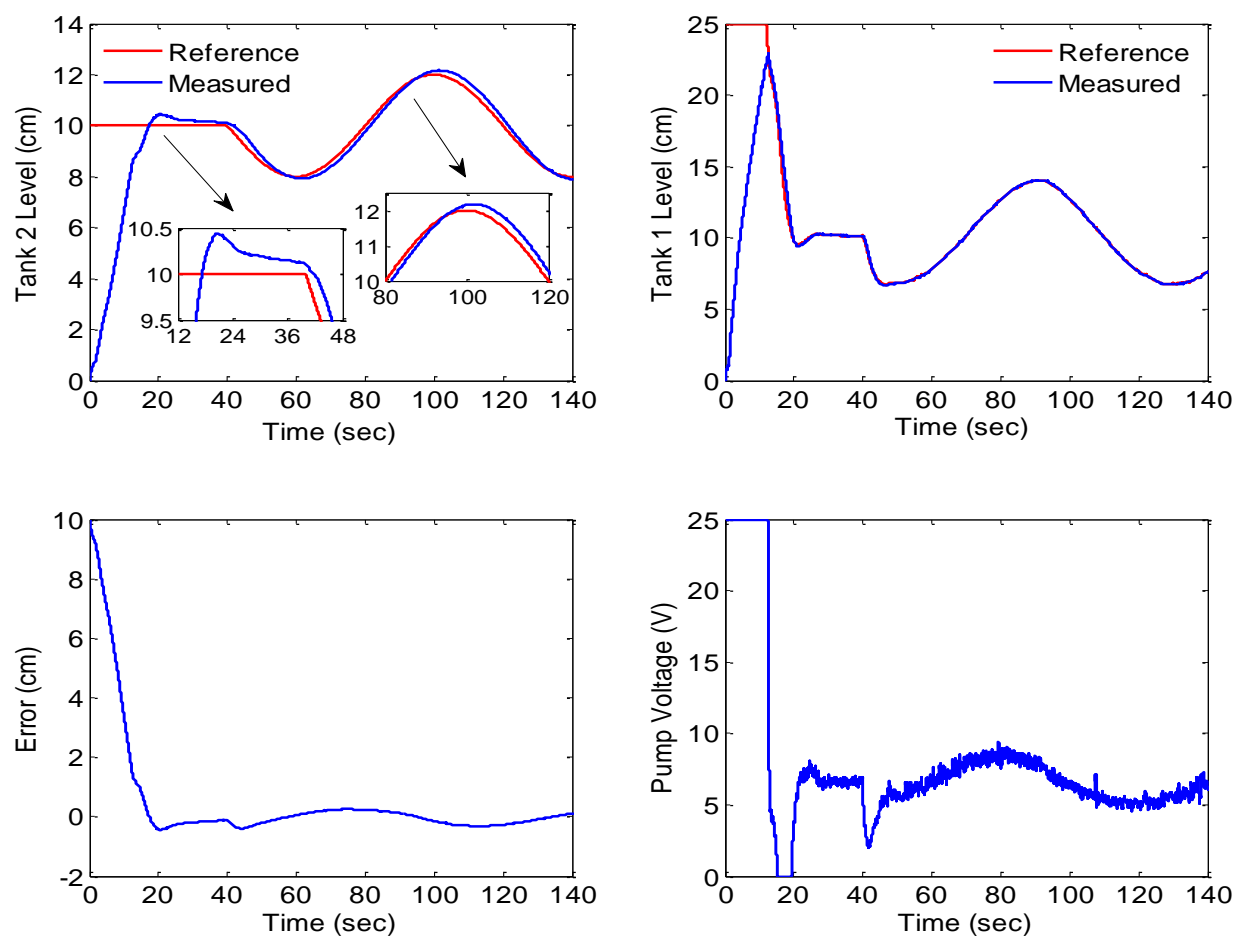

Figure 10. The Z-N based PI+FF controller results for coupled tank 


\section{CONCLUSION}

In this paper, the GA and Z-N optimization methods have been used to obtain PI+FF controller's parameters to realize liquid level control of tank system. The obtained parameters by two optimization methods are tested in real time in terms of reference tracking performances, error elimination capability and compared to their ability to respond quickly to the sudden reference changes. For single tank, although both optimization-based PI controllers performed similarly, the GA based PI controller has provided an improvement of $12.20 \%$. Also, for sudden chances applied for single tank, the GA based PI controller is able to set to reference without overshoot compared to the Z-N based PI controller. Besides, for coupled tank, the GA based PI controller has set the reference with less overshoot and also followed the sinusoidal reference signal with minimum deviation when it is compared with the Z-N based PI controller's result. Moreover, the GA based PI controller has provided $68.79 \%$ total improvement while tracking the whole reference signal compared to the Z-N based PI controller. As a result, the GA gives more successful results than the Z-N method due to its advantages such as researching the fitness function in a wide spectrum, studying with multiple parameters, obtaining more than one optimum solution, and optimizing complex fitness function parameters.

\section{Conflict of Interest}

The article authors declare that there is no conflict of interest between them.

\section{Author's Contilbutions}

The authors declare that they have contributed equally to the article.

\section{REFERENCES}

Abiodun FT, Habeeb BS, Mikail OO, Wahab NA, 2013. Control of a Two Layered Coupled Tank: Application of IMC, IMC-PI and Pole-Placement PI controllers. International Journal of Multidisciplinary Sciences and Engineering, 4(11): 1-6.

Başçi A, Derdiyok A, 2016. Implementation of an Adaptive Fuzzy Compensator for Coupled Tank Liquid Level Control System, Measurement, 91(2016):12-18.

Çelebi M, Başçi A, 2016. Fractional Order Control of A Sinusoidal Output Inverter. Istanbul UniversityJournal of Electrical and Electronics Engineering, 16(2): 3037-3042.

John JA, Jaffar NE, Francis RM, 2015. Modelling and Control of Coupled Tank Liquid Level System using Backstepping Method. International Journal of Engineering Research \& Technology, 4(6): 667-671.

Khalkhali A, 2016. Control of Two Tank System with Genetic Algorithm. Atatürk University Graduate School of Natural and Applied Sciences, Master Thesis (Printed).

Katal N, Kumar P, Narayan S, 2014. Optimal PID Controller for Coupled-Tank Liquid-Level Control System Using Bat Algorithm. 2014 International Conference on Power, Control and Embedded Systems (ICPCES), Allahabad, December 26-28, 2014, pp: 1-4.

Lian ST, Marzuki K, Rubiyah Y,1998. Tuning of a Neuro-Fuzzy Controller by Genetic Algorithms with an Application to a Coupled-Tank Liquid-Level Control System. Engineering Applications of Artificial Intelligence, 11(4): 517-529.

Liang L, 2011. The Application of Fuzzy PID Controller in Coupled-Tank Liquid-Level Control System. 2011 International Conference on Electronics, Communications and Control (ICECC), Ningbo, September 9-11, 2011, pp: 2894-2897. 
Mohideen KA, Saravanakumar G, Valarmathi K, Devaraj D, Radhakrishnan TK, 2013. Real-Coded Genetic Algorithm for System Identification and Tuning of a Modified Model Reference Adaptive Controller for a Hybrid Tank System. Applied Mathematical Modelling, 37(6): 3829-3847.

Nawi SM, Abdalla AN, Ramli MS, 2011. Improved Coupled Tank Liquid Levels System based on Hybrid Genetic-Immune Adaptive Tuning of PI Controller. International Conference on Electrical, Control and Computer Engineering 2011 (InECCE), Pahang, June 21-22, 2011, pp: 247-252.

Ogata K, 2010. Modern Control Engineering, Prentice Hall, New Jersey.

Sekban HT, Can K, Başçi A, 2020. Model-based Dynamic Fractional-order Sliding Mode Controller Design for Performance Analysis and Control of a Coupled Tank Liquid-level System. Advances in Electrical and Computer Engineering, 20(3): 93-100.

Singh SK, Katal N, Modani SG, 2014. Multi-Objective Optimization of PID Controller for CoupledTank Liquid-Level Control System Using Genetic Algorithm. Proceedings of the Second International Conference on Soft Computing for Problem Solving, New Delhi, December 28-30, 2014, pp: 59-66.

Tijjani AS, Shehu MA, Alsabari AM, 2017. Performance Analysis for Coupled - Tank System Liquid Level Control Using MPC, PI and PI-plus-Feedforward Control Scheme. J Robotics Autom, 1(1): 42-53.

Quanser manufacturer, Two Tank Manuel, 2005. 